https://doi.org/10.18485/fb_godisnjak.2019.9

\title{
ОНУФОВА ТЕОРИЈА ГОВОРНИХ АКАТА - ИМПЛИКАЦИЈЕ НА ИСТРАЖИВАЊА У ОБЛАСТИ БЕЗБЕДНОСТИ
}

Невена Станковић, студенткиња докторских студија

Универзитет у Београду, Факултет безбедности

stankovicnevena649@gmail.com 



\section{ОНУФОВА ТЕОРИЈА ГОВОРНИХ АКАТА - ИМПЛИКАЦИЈЕ НА ИСТРАЖИВАЫА У ОБЛАСТИ БЕЗБЕДНОСТИ}

Сажетак: У исйраживачком фокусу овоїа раgа налази се тиеорија і̄о-

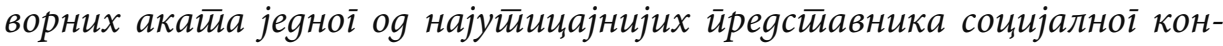
ситрукииивизма - Николаса Онуфа (Nicholas Onuf). Након ириказа најзначајнијих Онубових сииавова у вези са ирравилима, као ктучним иоомом

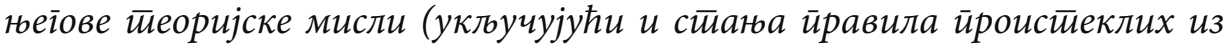
юих), ауйор указује на улоїу и значај иеерформайивноі̄ језика у домену

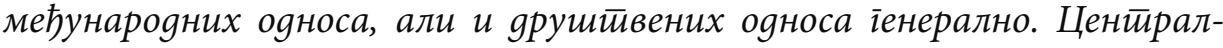

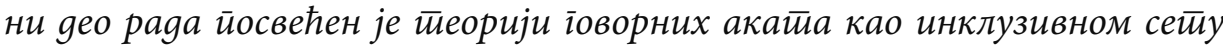

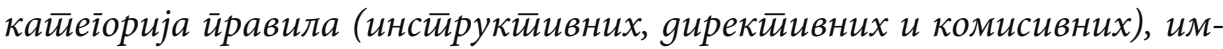
иллкацијама овако извеgених ӣравила на аиеентирру и уоченој сиррези са леїалношћу међунаровноі йоретика. Найослетику, ауйор износи зактучике о ирредностимма и моіућностима йримене Онуфове йеорије іоворних

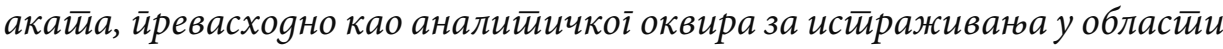
безбедностии, као и о уоченим неgоситацима, уз суіестиије у иравиу юи-

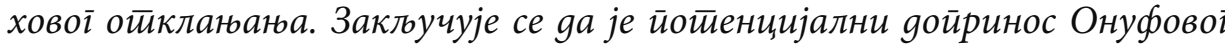
ирромишльаға о овој ироблемаииици на йољу безбеgносиии, али и међународних оgноса, изузетино значајан, али gа је за већу ексйланайорну ӣри-

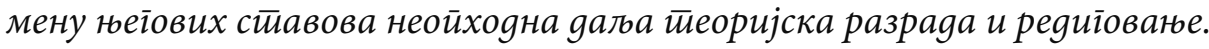

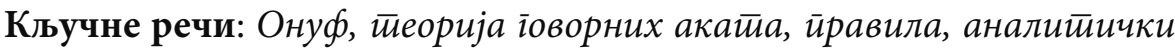
оквир, истираживана у обласиии безбедносиии. 


\section{Уводна разматрања}

Полазећи од одређења самог конструктивистичког правца у области међународних односа, а имајући у виду његову комплексност, преплитање крајње различитих теоријских полазишта и идеја различитих аутора, у академској заједници отворено је питање да ли се у том случају уопште може говорити о теорији као таквој. Чини се најпримереније рећи да је реч о метатеорији, или пак, о широком спектру теоријске мисли различитих аутора у настојању да надоместе уочене недостатке претходно доминантних теоријских праваца, превасходно комбиновањем препознатих предности сваког од њих. Или, како то Онуф илустративно објашњава, реч је о „начину проучавања друштвених односа - било које врсте друштвених односа“ (Onuf, 2013: 3). „Позајмљујући“ теоријске поставке и појмове из различитих начина проучавања друштва, конструктивизам, напослетку, није и сам теорија. „Он не нуди опште објашњење онога што људи чине, зашто се друштва разликују, како се свет мења. Уместо тога, конструктивизам чини изводљивим теоретисање о стварима које изгледају неповезане зато што су појмови и претпоставке који се уобичајено употребљавају у говору о таквим стварима такође неповезани“ (2013: 3). У том смислу, постоје основе за тврдњу да конструктивизам не само да није теорија међународних односа, него није ни теорија било које врсте друштвених односа. То је разматрање различитих теоријских промишљања која се баве проучавањем друштвених појава, са фокусом на међународне односе (Ковачевић, 2016: 77). Друкчије речено, реч је о метатеорији која, можда, може осветлити логичке, онтолошке или епистемолошке проблеме различитих теорија. Неоспорно је да теоретисање о стварима које су наизглед неповезане и испитивање могућих веза међу појмовима који се користе у различитим наукама може бити занимљиво и отворити нова виђења проблема, односно произвести неочекивана сазнања (2016: 77).

\section{Онуфово поимање правила}

Суштина конструктивистичког приступа оличена је у тези да су, уз материјалне чиниоце, једнако важан аспект међународних односа и идеациони чиниоци, чиме се доводе у питање поставке доминантних теоријских струја (превасходно реалистичких, али и либералних), које су дуго времена у теорији биле уврежене и сматране непобитнима. Примењено на поље међународних односа, реч је о друштвено конструи- 
саној стварности, која постоји не само као споља дата стварност материјалних предмета, него и у облику заједничких идеја, правила, норми и институција (Ковачевић, 2016: 37).

И док инсистирање на улози и значају идеационих чинилаца представља својеврсну заједничку нит у промишљањима свих социјалконструктивиста, међу њима су приметно изражена различита (можда чак негде и дијаметрално супротна) поимања улоге и значаја конкретног чиниоца коме се даје примат, односно релативна тежина која се идејама, правилима, нормама, праксама и сличним „конструктима“ придаје, али и садржај који се под њима подразумева. Тако, за разлику од Онуфа по коме су правила пресудна, централни појам у приступу Александра Вента (Alexander Wendt) представљају идеје, док су код Фридриха Кратохвила (Friedrich Kratochwil) то норме, у знатно ширем значењу од онога које Онуф подразумева под правилима.

Конструктивистички приступ Николаса Онуфа полази од претпоставке да људи креирају друштво, као и да друштво креира људе. Реч је о континуираном, двосмерном процесу. У циљу разумевања овог процеса, неопходно је поћи од средине, негде између људи и друштва, што Онуф чини увођењем трећег елемента - иравила. Правила су, према његовом мишљењу, спона између људи и друштва. Друштвена правила (укључујући и правна правила) омогућавају овај процес путем којег људи и друштво конституишу једни друге, континуирано и реципрочно. Премда је овакво полазиште начелно заједничко конструктивистичким промишљањима у целини, особеност Онуфовог схватања се огледа у фокусирању на правила, и то правила која полазе из ума и генерисана су путем релација међу партнерима (Onuf, 2013: 8). На овакав начин одређена, правила у крајњем резултирају међународним друштвом, насталим узајамном конституцијом држава као суверених партнера. „Креирањем, поштовањем и говорењем о правилима, људи конституишу многоструке структуре друштва“, док истовремено „путем тих правила друштво конституише људе као агенте“ (2013: 6-7).

Јасно је из наведеног да се правила о којима Онуф говори никако не могу свести на правила/норме о којима, примера ради, говори Вент. Вент говори о њима искључиво у контексту институција, истичући да су институције сачињене од правила и норми који су “идеационе појаве или заједнички ментални модели” (Вент, 2014: 85), дакле ништа више до ментални склопови или конструкције. Према Онуфу, међутим, правила су тврдње које људима налажу шта би требало да чине (Onuf, 2013: 4). Оно што се налаже заправо представља својеврсни стандард понашања који се од људи у конкретним ситуацијама очекује. Чињеница да 
би нешто требало да чинимо наводи нас да поступамо по очекиваном стандарду. Уколико не поступамо у складу са оним што правила налажу, можемо очекивати последице настале дејством неког другог правила, онда када други људи поступају по правилу које те последице производи. Начини на које се људи управљају према правилима, било да их поштују, крше, односно праве, мењају или поништавају, уобичајено се називају йраксом (деловањем) (2013: 4).

У свом капиталном делу World of our making, Онуф нашироко пише о правилима, како би био сигуран да читаоци под тим термином неће подразумевати искључиво правна правила или закон. Марта Финемор (Martha Finnemore) поставља питање да ли правне норме, као врста, оперишу другачије од било које друге врсте норми, сугеришући притом одричан одговор (Wiener, 2017: 120, цитирано према Finnemore, 2001: 701). То је управо тачка са које Онуф у свом разматрању полази. Како су правна правила формално успостављена, своје важење остварују позивањем на закон као свој извор, те су подржана од стране других правних правила која спецификују последице њиховог кршења, јасно је да се ниједно друштво не ослања у потпуности и искључиво на таква правила. Штавише, постоје друштва за која је та врста правила непозната категорија. Дискусија по питању да ли је међународно право право у наведеном смислу речи, производи концептуална извртања која су збиља непотребна уколико се не захтева да се под правилом сматра само оно које је формално установљено, прихваћено или спроведено (што Онуф не чини). Значајнија је чињеница да се друштва ослањају и на друге врсте правила, што нарочито важи за међународну заједницу.

Након овако уопштено представљеног погледа на правила, Онуф даље разрађује своје ставове, полазећи од претпоставке да је целокупно људско понашање одређено правилима синтаксе и логике (која утичу на когнитивне способности), а што коначно утиче на све ступњеве индивидуалног и колективног понашања, укључујући и такозвано “мећународно понашање” (Puchala \& Kegley, 1989, X). Формулисање теорије о међународним односима је стога најприкладније учинити на основу ових фундаменталних правила, објашњавањем њихових извора и елаборацијом њихових импликација на људску праксу (1989: X)1.

1 Како Онуф истиче, поласком од правила неминовно се долази до схеме односа која се једино може одредити као правило (једнина), односно стање правила (conditions of rule) (Onuf, 2013: 7). Стање правила представља други кључни појам његовог конструктивизма, а како и сам верује, друго кључно обележје политичког друштва (након правила (множина)) (Onuf, 1989: 22). Парадигма политичког друштва заправо повезује condition sine qua non друштва - доступност, односно неизбежност правила и политике - истрајност асиметричних друштвених односа, одређених као стање правила (1989: 22). Онуфово бављење правилима заправо представља третман друштвених односа уопште, док бављење правилом сужава фокус на међународне односе. Како правило или стање правила није најнепосредније у вези са темом овога рада, у наставку ће интересовање бити усмерено искључиво на Онуфово поимање правила проистеклих из говорних аката. 
Упутно је на самом почетку, а у вези са појмом йравила (множина), указати на Онуфов особен став о њиховој истовремено регулативној и конститутивној функцији. Управо уважавање могућности да једно правило истовремено буде и регулативно и конститутивно, представља новину у теоријским промишљањима о правилима у области међународних односа и један од најзначајнијих доприноса Онуфовог бављења овом проблематиком. Онуф је прилично јасан у својој критици ставова других конструктивистичких аутора (са изузетком Фридриха Кратохвила ${ }^{2}$ (Friedrich Kratochwil)) о правилима, односно нормама (Katzenstein, 1996; Klotz, 1996; Ruggie, 1998). Наводећи да многи теоретичари међународних односа почињу себе да називају конструктивистима, те да говоре о нормама, Онуф истиче да је кључни недостатак код њих што не објашњавају шта је то што норме чини нормативним ${ }^{3}$. Назовиконструктивисти и остали либерални мислиоци, како их назива, о правилима и њиховим обележјима говоре апстрактно, закључујући да правила по својој функцији могу бити или реїулатиивна или констиитичйивна (Onuf, 2014: 4).

Питер Каценстајн (Peter Katzeinstein) у уводном делу зборника The Culture of National Security: Norms and Identities in World Politics, наводи да се концепт норми користи за описивање колективног очекивања пожељног (адекватног) понашања агента са датим, одређеним идентитетом (Katzenstein, 1996: 3). Даље наводи да у неким ситуацијама норме функционишу као правила која дефинишу идентитете агената, те имају конститутивни ефекат који конкретизује које акције ће довести до тога да релевантни Друіи препознају конкретан идентитет. Истиче и да постоје оне друге ситуације, у којима норме функционишу као стандарди који конкретизују пожељно (адекватно) понашање у односу на већ дефинисан идентитет, те имају регулативни ефекат који конкретизује стандарде исправног понашања. Супротно овако изведеном закључку о нормама, које „или дефинишу (конституишу) или прописују (регулишу) понашање“ (1996: 3), Онуф тврди да сва правила, по дефиницији, имају регулативне ефекте на понашање, истовремено на тај начин конституишући социјалне аранжмане у оквирима у којима функционишу. Премда је регулативна функција правила (свих правила) у служби повезивања агената у континуирано мењајућем свету, управо је таква његова структура производ конститутивне функције правила (Onuf, 2014: 4).

2 Кратохвил објављује своје дело Rules, Norms and Decisions такође 1989. године, када и Онуф World of Our Making. Онуф у својим каснијим делима експлицитно наводи Кратохвила као јединог аутора који у то време уочава значај норми на пољу међународних односа.

3 Поменути теоретичари разликују норме од правних правила, не улазећи у изворе њихове нормативности. Ограничени на уочавање норми свуда, Онуф наводи да они нису ништа више до нова генерација либералних институционалиста који се пробијају на свом путу у пољу дуго времена доминантног политичког реализма. Површно су схватали конструктивизам (њихов конструктивизам) као одговор на завршетак Хладног рата и дискредитованог реализма. (Onuf, 2014: 4). 


\section{Перформативни језик и нормативност}

Како би било јасније из ког разлога се Онуф у бављењу било којим аспектом међународних, али и друштвених односа уопште напослетку окреће ка правилима проистеклим из перформативног говора, упутно је указати на његово виђење друштва и науке као „ствари и процеса, низа текстова, и сходно томе, конверзацију путем текстова“ (Onuf, 1994: 1). Чињеница да само под одрећеним условима нормативност прати испуњавање обећања и обавеза, намеће потребу даљег истраживања нормативне праксе у ширем оквиру, у конституисању међународног друштва. У циљу општеприхваћеног разумевања нормативности (доласка до њеног конвенционалног одређења) на глобалном нивоу, неопходно је осврнути се како на извор обавезивања, а што представља говорни акт обећања и његово прихватање, тако и на развој нормативности кроз серије потоњих говорних аката (Wiener, 2017: 119). Уопштено говорећи, говорни акт је исказ чија је функција остваривање комуникације и представља акт за себе (2017: 119). Теоретичари међународних односа, ослањајући се на учења Лудвига Витгенштајна (Ludwig Wittgenstein), Џона Остина (John L. Austin) и Џона Серла (John Searle), окренули су се теорији говорних аката како би повезали значење и деловање (Fierke \& Wiener, 1999; Adler, 2008; Pouliot, 2010; Zaiotti, 2011). Како наводи Чарлс Тејлор (Charles Taylor), “пракса не само да испуњава правило, већ му даје и конкретан облик у конкретним ситуацијама. Пракса је ... континуирана интерпретација и реинтерпретација правог значења правила" (онога што правило заправо јесте) (2017: 119). Поменути теоретичари су користили овај концепт с циљем истраживања утицаја који исказ има у интеракцијама на међународном плану на конституисање међународних односа. Отуда реконструкција нормативности путем социјалних интеракција заправо значи потребу да се крене од примарних елемената перформативног говора ${ }^{4}$.

Онуфов приступ, такође, полази од учења Витгенштајна и Остина. Конкретно, Витгенштајнову основу користи за развијање концепта о конститутивној улози језика као друштвене праксе. Према мишљењу Онуфа, Витгенштајн је својим каснијим радовима припремио терен за конструктивистички пројекат друштвене теорије. Па ипак, Онуф сматра да Витгенштајнова теорија није конструктивистичка (Guzzini \& Leander, 2017: 179). Упркос прилично оштрим критикама које му упућује, Онуф налази да круцијални допринос његове теорије лежи у инсистирању на

4 Онуф разликује репрезентативну и перформативну функцију језика. Перформативни језик би обухватао сваки исказ или говорни акт путем кога намеравамо да утичемо на оно што други чине (искључиво путем тог говорног акта). 
употреби језика, што се директно доводи у везу са начином на који су према Онуфовом схватању повезана правила и пракса. Он се не задржава, међутим, на овако уопштеном социолингвистичком приступу теоријама говорних аката, већ настоји продрети дубље у анализу теорија о друштвеним правилима уопште (Weber, Parsons, Giddens). Незадовољан начином на који се у тим теоријама правила третирају, Онуф се окреће лингвистичкој теорији говорних аката Џона Остина, са циљем креирања још конкретнијег и специфичнијег концепта правила.

Највећу вредност Остинове теорије Онуф проналази у разликовању три врсте говорних чинова - локуционих, илокуционих и перлокуционих. Према Остину, „локуциони чин је оно што се говори, илокуциони је оно што се хоће изговарањем постићи, а перлокуциони чин је ефекат који се постиже изговарањем“ (Ејдус, 2016: 206, цитирано према Остин, 1980). Онуф ове чинове види као три класичне категорије, односно начина на које правила функционишу, као и конкретних веза које остварују са праксом (Guzzini \& Leander, 2017: 180). Суштински допринос Остинове теорије језичких чинова види у стварању основа за извођење закључака о перформативној улози језика и последично у нагласку на (ко)конститутивности, на којој касније инсистира.

Онуфов фокус на перформативни ефекат језика (став да појединци и друштво континуирано конституишу једни друге путем правила, а да правила зависе од перформативне снаге језика) има корене још у учењу Аристотела ${ }^{5}$, односно у Аристотеловом општем моделу друштвених односа који неизбежно води до облика правила (Onuf, 2013: 141-160). У циљу репрезентовања појава (онога што представљају) и начина на који функционишу у узајамним односима, језик креира (ствара) појаве (укључујући и нас саме као агенте) какве јесу, креирањем света (било ког света друштвених односа) какав јесте (Onuf, 2013: 115). Свако од нас користи говор као инструмент (један од многих инструмената које нам језик чини доступним), како бисмо изнели своје индивидуалне намере - циљеве којима стремимо и које ценимо као прикладне нашим капацитетима. Па ипак, није могуће да у остваривању властитих намера успемо без партиципације других, како због језика који заједнички користимо, тако и због света - многоструких крајева (завршетака) и капацитета које стварамо за себе колективно (2013: 115).

Говорење (општење) је активност са нормативним последицама (2013: 116). Када говоримо, наше речи наводе друге да очекују да ћемо

5 Сам Онуф наглашава аналогију властитог одређења правила са Аристотеловим схватањем правила оличених у перформативном језику. Више о овоме у Making Sense, Making Worlds, 2013. 
поступати на одређени начин, у складу са изреченим намерама. Наше речи (изговорене) су од значаја и за нас саме. Самим тим што су изговорене, такве намере и планови садрже известан степен нормативне снаге. Онуф инсистира на неизбежној повезаности индивидуалних говорних аката и правила која, било да поступамо у складу са њима или не, симултано конституишу и регулишу наше социјалне аранжмане (2013: XXIV). У средиште свог интересовања ставља откривање и објашњење начина на који правила фукционишу, чинећи наше вештине (активности) ефикаснијим у постизању наших крајњих циљева.

У вези са самим појмом правила, Онуф сугерише да постоје одређени услови који морају бити испуњени како би се нешто уопште могло сматрати правилом (Roberts, 2017: 86). Према његовом мишљењу, правила су искази (тврдње) или бар морају бити у стању да нешто тврде (налажу). Даље, правило мора да представља специфичну категорију акција, као и да идентификује оне акције на које се односи (примењује). Такође, правило одређује (указује на) поступке који представљају поступање по њему, као и поступке који то не чине. Правила би, уз поменуто, требало и да наводе на поступке који представљају поштовање тог правила, односно, правила морају садржати примесу нормативности. Како су правила искази, оличена (отелотворена) су у језику.

Резимирано, перформативни говор формализује правила (Onuf, 1989: 136). Основно својство перформативног језика (било ког његовог исказа или говорног акта) јесте намера да њиме утичемо на поступке (деловање) других људи (Tickner, 2017: XXIV). Вођени језиком и његовим правилима, ми креирамо правила као и стање правила, стварајући на тај начин свет каквим га видимо (2017: XV). Премда се овако представљено суштинско интересовање Онуфа за правила може чинити превише уопштеним, односно присутним и код других помињаних теоретичара који су признавали улогу и значај перформативног говора у мањој или већој мери, овакво схватање постаје особено када се има у виду Онуфов став да правила, односно говорни акти из којих она проистичу, претходе и друштву и људима, тако што „правила ограничавају вршење избора одређујући средства и циљеве доступне доносиоцима одлука“ (Onuf, 1989: 258). Чини се да је реч о настојању да се лингвистичка правила (говорни акти) подигну до нивоа нормативних друштвених правила. Оваква Онуфова тврдња, међутим, може имати основа искључиво уколико се разумева у смислу да правила, схваћена на његов начин, ограничавају наше виђење (разумевање, поимање) свега што нас окружује, односно света чији смо део. 


\section{Онуфова теорија говорних аката}

Критиком превасходно легалистичких или легалистичко-позитивистичких теорија говорних аката, Онуф покушава да створи сопствену варијанту теорије говорних аката, а што резултира инклузивним сетом категорија у који сва правила могу бити сврстана (Onuf, 1989: 66). Ове категорије су идентификација различитих начина на која су правила истовремено регулативна и конститутивна. Да ли говорни акти производе правила, зависи од глагола који су изабрани и ефеката који ови искази намеравају да произведу. Да би се знало који су говорни акти (осим асертива, односно тврдњи) кандидати за правила, потребна је листа глагола коришћених у лингвистичком смислу за постизање утицаја на друштвене акције, или боље, класификацијска схема категорија говорних аката. Онуф сматра да је шема Џона Серла' ${ }^{6}$ кључна како би теорија говорних аката могла постати друштвена теорија, односно, у контексту друштвене акције то је прикладна схема (1989: 86-87). Серл нуди пет категорија говорних аката: асертиви (тврђења, извештаји), директиве (упутства, наредбе), комисиви (обећања, претње, са обавезујућом снагом у будућности), експресиви (извињења, захваљивања, честитке, са указивањем на психолошко стање говорника) и декларативи (искази који изазивају тренутну промену неког стања) (1989: 87).

Користећи категорије говорних аката које је понудио Серл, Онуф верује да је идентификовао три категорије правила - категорије схваћене у традиционалном смислу термина апстрактних „контејнера“ (складишта), са појавама унутар и изван категорије (1989: 23). Ове категорије произилазе из разматрања језика као нечега што омогућава људима да изводе друштвене акте и остварују циљеве креирањем асертивних, директивних и комисивних исказа. У складу са значајем који придаје перформативном говору, Онуф изоставља Серлове две категорије - експресиве и декларативе, као говорне акте који немају могућност утицаја на понашање Друі̄ō. Како наводи, једном свестан ових категорија, Серл је уочио бројне варијације истих у многим текстовима, класичним и савременим, које су му привукле пажњу. Уочио их је нарочито у великим теоријама, које су теоретичари међународних односа узимали као централно место анархије за међународне односе и у дискусијама о стању правила. Будући да се ове категорије једнако примењују на правила и правило, види их као значајну подршку те дихотомије, одлучујуће за политичко друштво (1989: 23). С обзиром да се заснивају на читавом спек-

6 Више о класификацији говорних аката у Серловом делу “Говорни чинови: Оглед из филозофије језика" (1991). 
тру људске праксе за коју је политичко друштво оперативан термин, нужне су за сортирање материјала које пажљивим читањем омогућава извођење значајних конструктивистичких закључака. Онуф сматра да не постоји ништа изненађујуће или оригинално у вези са његовим методом, који сеже чак до Аристотелат (1989: 23).

Према Онуфовом мишљењу, постоје само три фундаменталне категорије говорних аката: асертивни, директивни и комисивни. Говорни акти помажу говорницима у остваривању циљева путем ефекта који остварују на друге, односно, они су нужно социјални, а сврставају се у поменуте категорије у складу са начином на који функционишу. Асертивни говорни акти траже од слушаоца да “прихвати предложени садржај; одбијајући или игноришући чињеницу да такве тврдње ограничавају њихов утицај на стање света" (Wiener, 2017: 120). Директиве очекују од слушаоца да "прихвати извршење предочених задатака као властитих; одбијајући или игноришући чињеницу да директиве спречавају говорникове напоре да промени свет" (2017: 120). Комисивни говорни акти позивају слушаоца да “прихвати говорникове намере да промени свет; одбијајући или игноришући чињеницу да комисивни акти не спречавају говорнике толико будући да их ослобађају онога што би требало да представља обавезу да промене свет" (2017: 120).

Кључна претпоставка Онуфове теорије говорних аката јесте да три типа правила која уводи представљају шаблон, те да су функционално аналогна трима категоријама говорних аката (Onuf, 2014: 4). Свако од правила производи различите функције за агенте и структуре, у складу са властитим обележјима. Асертивни говорни акти креирају инструктивна правила тврдњом о стању ствари по ком би слушалац требало да поступа (Roberts, 2017: 86). Директивни говорни акти креирају директивна правила указивањем на поступке које говорник очекује да слушалац изврши (2017: 86). Комисивни говорни акти креирају комисивна правила, обезбеђујући правац деловања којим се говорник везује онда када је такво правило прихваћено од стране слушаоца (2017: 86). Уобичајени елемент оваквих класификација јесте онај који подразумева да говорник користи језик како би навео слушаоца да нешто учини (навео на акцију). Значајно је истаћи и да Онуф експлицитно прихвата могућност да су говорник и слушалац иста (једна) особа, барем у контексту комисивног правила (Onuf, 1989: 88).

7 На овом месту се превасходно мисли на аналогију са Аристотеловом трипартитном концепцијом politeie, односно са стањем правила карактеристичним за монархију, аристократију и политеју. Више у World of Our Making (1989) и Rule and Rules in International Relations (2014). 
Дакле, према Онуфу постоје три типа различитих и међусобно искључивих говорних аката: асертивни (ја тврдим, констатујем...), директивни (ја захтевам...) и комисивни (ја обећавам...), који су концептуализовани као основа перформативног говорног језика и самим тим представљају базу стварања правила. Инструктивна правила имају нарочито значајну улогу у конструисању друштвених институција, укључујући и изворе националног интереса (Marlin-Bennett, 2017: 148). Тврдити шта нешто јесте, са снагом изјаве, навести слушаоца да разуме тврдњу, заправо значи створити круцијалну онтолошку тврдњу о свету, "ко одлучује шта је, односно, шта свет није” (2017: 148). Садржаји тврдњи које су прихваћене као инструктивна правила фундаментални су за социјалну конструкцију. Директивна и комисивна правила су на известан начин зависна (или можда чак произилазе) од инструктивних.

Сва друштвена правила, не само инструктивна, нужно су и истовремено конститутивна и регулативна. Уколико производећи инструктивна правила асертивни говорни акти имају и конститутивни и регулативни карактер, отвара се питање да ли свако правило има овакве ефекте или само она која произилазе из асертива. Овде је потребно вратити се на чињеницу да говорни акти чине језик перформативним. Асертацијом (тврђењем, изјављивањем) неко чини нешто друштвено, барем уколико нечији исказ добија одговор - било какав одговор (Onuf, 1989: 86). Па ипак, асертације тешко да исцрпљују спектар могућих говорних аката, више него што сва друштвена правила дају инструкције.

У свом делу World of our making, правила која се доводе у везу са законом (страх као мотивација за поштовање закона) Онуф назива директивним правилима. Инструктивна правила су, каже, попут рецепата у куварима, објашњавају начин на који је потребно да агенти поступају како би остварили прижељкивани резултат (Onuf, 2014: 3). Примедба упућена овим правилима јесте да нису ни обавезујућа, нити применљива (у извршном смислу) (2014: 3). Из наведеног, јасан је претеран утицај легалистичког начина размишљања. У случају непридржавања инструктивних правила, агентима ће бити теже да постигну оно чему се надају. Међутим, ова правила се могу поштовати и без даљег размишљања о томе на шта се односе, или пак, придајући томе огроман значај. Уколико их игноришу, Онуф верује, агенти ће вероватно доћи у ситуацију да их други подсећају на значај, или прецизније - потребу да учине оно што ова правила налажу. Неретко сама чињеница да бивају подсећани производи код ових агената осећај срамоте (2014: 3). Значајно је истаћи и да су правила која Мортон Каплан (Morton A. Kaplan) назива есенцијал- 
ним $^{8}$, заправо инструктивна правила која се уобичајено називају йринцииичма. Комисивна правила су попут уговора склопљених како би се осигурао жељени заједнички резултат. Када се генерализују на друштво као целину, она постају оно што се данас подразумева под правима и дужностима (2014: 3). Правила ове врсте стављају нагласак на размену (неспоразуми о правима и дужностима се најчешће усмеравају ка трећој страни у циљу разрешења, док неуспех у остваривању својих дужности често доводи до осећаја кривице). Споразуми су типичан пример комисивних правила, а њихово обиље је значајна карактеристика савременог међународног друштва.

\section{Правила и агентура}

Када је реч о спрези овако одређених правила и агентуре, значајно је указати на неколико импликација. Инструктивна правила додељују статусе људима и институцијама, придајући значај разликама које дефинишу статусне групе или кохорте. Статусне кохорте су мрежно организоване, успостављајући на тај начин статусну хијерархију. Када мрежну организацију посматрамо са аспекта њених “чворова”, чланови статусних кохорти заузимају јединствен ниво, што их чини статусно једнаким. Са друге стране, када је посматрамо из аспекта њених „спајајућих нити“, чланови заузимају различите нивое и стога су стратификованог распореда. Према мишљењу Харолда Лазвела (Harold Lasswell) и Абрахама Каплана (Abraham Kaplan), статус најдиректније произилази из вредности коју чланови и друштво придају изражавању различитости (титулама, признањима и слично) ${ }^{9}$ (Onuf, 2014: 5).

Директивна правила додељују положаје/службе (у смислу моћи и дужности), организоване према рангу у опадајућем низу, на тај начин конституишући организацију. Термин “ранг” је примењиван на позиције у статусним кохортама (статусна хијерархија), што је према Онуфу погрешно. У циљу терминолошке јасноће Онуф прави разлику између статусне позиције и ранга, користећи термин "ранг” само када је реч о положају/служби са међусобно упоредивим моћима и дужностима. Број припадника кохорти једног нивоа показује тенденцију опадања у

8 Мортон Каплан, професор емеритус Универзитета у Чикагу, увео је нову аналитичку методу у проучавање међународних односа - системску анализу. Наводи шест есенцијалних правила за одржавање равнотеже моћи. Више у Review of Morton Kaplan's Justice, Human Nature, and Political Obligation (1997).

9 Онуф преузима овај став из Лазвеловог и Каплановог дела Power and Society: A Framework for Political Inquiry, 1965. 
односу на сваку наредну (вишу), ретко је фиксно одређен и не показује функционалне везе са неспосредно вишим/нижим позицијама. Супротно томе, рангови су најчешће фиксни у обиму и функционално повезани са претходним/наредним рангом.

Комисивна правила додељују улоге, попут оних у позоришној представи. Улоге се разликују у зависности од статуса или положаја/службе, превасходно с обзиром на чињеницу да је њихово поседовање добровољне природе, те да је њихова организација хоризонталног типа. У том смислу, сви су чланови јединствене статусне кохорте, односно статусно једнаки. Без обзира на то колико се њихове улоге разликују (могу бити савезници, ривали или непријатељи), они конституишу асоцијацију.

Додељујући статусе, положаје (службе) и улоге, правила конституишу агентуру за људе и њихове институције. На тај начин је сваки агент у позицији да дела у свету, али увек у оквирима граница спецификованим од стране истих правила. Ниједан агент нема идентичну комбинацију статуса, положаја и улога као неки други агент, односно сваки агент је јединствено друштвено биће. И докле различита друштва преферирају ова или она правила приликом конституисања агентуре, крајњи резултат је да људи постају “егоцентрични”, што не значи нужно и “индивидуалисти” (Onuf, 2014: 5). Начин на који агенти делају у друштву зависи још и од њихових циљева и мотивације, као и расположивих средстава за остварење тих циљева.

\section{Легалност међународног поретка}

Најзад, Онуф доводи у везу са овако изведеним правилима и легалност (законитост) међународног поретка. Уопштено посматрано, легалност система се одређује у односу на степен до ког су правила формално уобличена, њихова екстерна димензија подржава институционализацију, лична одговорност агената за формализацију и институционалну подршку правилима специфично и формално приписана овим задацима, за које су неретко посебно обучени (Onuf, 1989: 136). Иако повезана на комплексан начин, ова три критеријума су и међусобно одвојива. Степен до ког је сваки испуњен у конкретном случају правила може се, мада и не мора, подударати. Такав несклад нарочито је очигледан у случају међународног система, а што отвара питање да ли уопште постоји легалан међународни систем. Јасно је да, чак и када су сва три критеријума испуњена, може се десити да поредак није легалан. За легалистичке позитивисте (H. L. A. Hart, G. Gottlieb, J. S. Austin) коначна оцена 
легалности поретка представља поседовање суверенитета. Услов суверенитета захтева да формално повезан сет правила оперише ексклузивно у различитим временима и просторима (1989: 141).

Легалан међународни поредак је сет правила, чија кохерентност произлази из праксе повезане са формалном и институционалном подршком правила. Поврх свега, према мишљењу Онуфа, легални међународни поредак је “правничка конструкција" (1989: 144). Правници су ти који сету правила дају кохерентност која му недостаје (1989: 144). Мањег обима, али кохерентнији, сетови правила уочени у међународним односима су међународни режими. Режими поседују свој карактер, односно властити домашај и кохерентност, у оквирима датог поља међународних односа. Значајно је, међутим, да су правила та која пружају било ком режиму домашај и кохерентност разграничавањем улога (1989: 145). Што су ова правила формалнија и институционално подржанија, то је очигледније постојање конкретног режима. Као мање или више самосталан сет правила, међународни режими комбинују инструктивна, директивна и комисивна правила, од којих свака имају властити удео ${ }^{10}$.

\section{Допринос Онуфове теорије студијама безбедности}

Неоспоран допринос студијама безбедности дала је Копенхашка школа, која безбедност конципира као „процес социјалног конструисања претњи који укључује секуритизујућег актера, који означава одређено питање као ургентно и као претеће по опстанак референтног објекта што, једном када публика то прихвати, легитимише употребу ванредних мера ради отклањања претње“ (Шуловић, 2010: 3). Безбедност се у теорији секуритизације концептуализује као језички акт. „Овако схваћено, безбедност није реч која упућује на нешто што је реално, већ само изговарање ове речи представља безбедносни чин. Говорећи речи, нешто је учињено“ (Wæver, 1995: 55). Самим чином говора о неком питању као

10 Значајан допринос Онуфовог одређења правила у међународним односима свакако има и увођење три идеална стања правила (conditions of rule) која настају из различитих типова правила (множина). Свака категорија правила (једнина) кореспондира са једном од три категорије правила (множина), која представљају решења за проблеме међународног друштва, настала путем социјалног карактера језика. Покушавајући да повеже делове парадигме међу собом, као категорије, Онуф изводи следеће закључке - хијерархија произилази из директивних правила, хегемонија из инструктивних правила, те хетерономија из комисивних правила (Roberts, 2017: 88). Свако од поменутих стања правила присутно је када је присутно понашање засновано на поступању по неким од типова правила (инструктивних, директивних или комисивних). У својој конструктивистичкој интерпретацији ове проблематике, Онуф повезује први стадијум са стицањем знања и способности коришћења инструктивних правила, други стадијум са директивним правилима и трећи стадијум са комисивним правилима (Onuf, 1989: 97). 
безбедносној претњи, оно постаје безбедносно питање, односно језички акт сам по себи постаје „аутореферентна структура“ (Шуловић, 2010: 4). Конструисање безбедносних питања путем језичких аката, међутим, није искључиво у рукама појединачног агента, већ је секуритизација „суштински интерсубјективни процес“ (Buzan, Wæver, de Wilde, 1998: 30). То је процес „константног преговарања између секуритизујућих актера који питање ставља на дневни ред и публике на којој је да наметнути дневни ред прихвати или не“ (Шуловић, 2010: 4).

Идејни творац теорије секуритизације је политиколог Оле Вевер (Ole Wever), који подразумева да је секуритизација „дискурзивно конструисање нечега у безбедносну претњу“ (Ејдус, 2016: 206). Попут Онуфа, и Вевер се ослања на радове Серла и Остина, концептуализујући безбедност као „говорни чин којим политичке елите идентификују претње, а од друштва захтевају легитимитет за примену специјалних мера које у нормалним условима не би биле прихватљиве“ (2016: 206). Вевер, међутим, секуритизујући чин види као илокуциони, за разлику од Остина, према коме је безбедност перлокуциони чин, којим „нешто извршавамо, односно постижемо казивањем“ (Остин, 1980: 127). У каснијим радовима Вевер и остали припадници Копенхашке школе безбедносни дискурс и сами одређују као перлокуциони чин (Ејдус, 2016: 206). И Онуф дели ово схватање, али и Остинову и Серлову употребу језичких аката „изнутра ка споља“ (2016: 207), односно од сувереног говорника ка сувереном слушаоцу.

Осим што Онуф ни на једном месту експлицитно не примењује своју теорију на безбедносну проблематику, задржавајући се на уопштенијим одређењима у вези са међународним односима и међународним друштвом, уочавају се и друге значајне разлике између његове теорије говорних аката и теорија секуритизације, примера ради, Вевера. У теоријама секуритизације се уобичајено говори о четири елемента - чину, секуритизујућем актеру, специјалним мерама и публици, с тим да се управо говорном чину, одређеном као „дискурс којим се одређени политички проблем формулише као посебно значајан за опстанак заједнице чиме се премешта ван поља утврђених правила игре“ (2016: 207), посвећује неспразмерно мала пажња. Супротно томе, централно место у Онуфовом поимању припада управо говорним актима, као полазишној основи за промишљање о било ком аспекту друштвене и међународне, а тиме и безбедносне стварности.

Приметно је, међутим, а што се уочава и као један од круцијалних недостатака Онуфовог бављења овом проблематиком, непридавање адекватне пажње самим актерима, односно говорницима и слушаоцима. Онуф ни на једном месту у свом излагању не конкретизује услове које 
је потребно остварити да би се могло говорити о носиоцу или примаоцу асертивног, директивног или комисивног говорног акта. Како је реч о примени на пољу међународних односа, додатно компликује разумевање и Онуфова тврдња да су међународни односи - односи међу државама као формално једнаким, сувереним партнерима (Onuf, 2013: 4). Тумачена у овом контексту, Онуфова интерпретација, мада нигде није експлицитно исказана, може се чинити блиском теоријама секуритизације, у смислу да се под секуритизујућим актерима или говорницима мисли на политичке елите. Имајући у виду Онуфов начелни став у вези са колективним као „фикцијом“ или каквом вештачком творевином која се у крајњем своди на појединачне агенте (Onuf, 2014: 88), јасно је да се Онуф никако не ограничава на овакву агентуру. Са друге стране, уколико се имају на уму његови ставови о агентури уопште, односно о условима за агентуру, а који су, чини се, прешироко постављени до мере да се готово свака индивидуа са способношћу говора и мишљења може сматрати агентом у некој ситуацији (Onuf, 2013: 3-20), постоје основи за тумачење да Онуф у коначници говори о друштвеним правилима у најуопштенијем смислу, што није нарочито применљиво на област међународних односа, а поготово на студије безбедности.

Са једне стране, овакво различито Онуфово схватање говорника, носиоца говорног чина, а тиме и креатора конкретног правила (наравно, под условом да постоји повратни одговор) носи извесне предности, будући да превазилази недостатке проистекле из устаљених схватања карактеристичних за традиционални концепт безбедности, према коме су државе најважнији, често и једини релевантан, субјект међународних односа. Будући да се спектар безбедносно релевантних субјеката у савремено доба шири муњевитом брзином, укључујући и владине и невладине организације, у извесном смислу медије, али и, несумњиво, појединце, Онуфов приступ чини се применљивијим, односно избегава се недостатак теорија секуритизације оличен у превише уском кругу потенцијалних секуритизујућих актера. Са друге стране, међутим, Онуфово одређење говорника, или бар претпостављени садржај који он под њиме подразумева, будући да га нигде прецизно не наводи, може се наћи на мети критика да је прешироко постављено. У крајњем, говорник чији се акт прихвати од стране слушаоца аутоматски постаје креатор правила - ко су онда индивидуе које то могу бити када је реч о унутардржавним или међународним односима? Како конституисање међународних норми више није ексклузивно право држава, а оне и те како могу садржати конфликти потенцијал (опажен на тај начин са неке стране), нужно је прецизно одредити услове да би се могло говорити о говорнику који постаје креатор правила, и то нарочито у случају дирек- 
тивних правила. Кредибилитет асертације нужно зависи и од статуса говорника, што само поткрепљује претходну сугестију.

Осим прецизнијег одређења говорника, Онуф се не бави у довољној мери ни слушаоцима. Да би се говорило о обавезивању, првенствено у контексту комисивног говорног акта и правила, а што је једно од значајнијих питања за међународне односе и међународну политику, мора се прецизно одредити и ко је слушалац, односно ко прихвата обавезивање. И у случају обећања мора бити експлицитно назначено о коме је реч, што Онуф, нажалост, нигде не чини, задржавајући се на прилично површном и уопштеном позивању на публику. Још важнијим чини се питање мотивације, односно зашто долази до пристајања или непристајања на норме у међународним односима, те који су то нормативни и практични услови потребни да би агенти пристали и да би те обавезе постале и легитимне.

Онуфова теорија говорних аката свој највећи допринос промишљању о међународним односима и студијама безбедности даје управо у претходно наведеном смислу. Конкретно, Онуфова настојања да препозна и отклони недостатке превасходно теорија легалистичког позитивизма, укорењене у уважавању само једне (конститутивне или регулативне) функције норми/правила, допринела су проширивању садржаја самог појма „правила“, резервисаног до тада углавном само за правне норме. Уочавањем истовремено и конститутивне и регулативне функције правила, омогућава се потпуније и свеобухватније разумевање не само норми, већ и свог друштвеног садржаја који Онуф под појмом „правила“ подразумева. Сам покушај подизања говорних аката на ниво општедруштвених правила, одговорних за креирање друштвене, међународне и безбедносне стварности, ипак се чини преамбициозним. За ставове попут оног о примату правила и у односу на друштво и на појединца, те генерално у односу на социјалну-конструисану стварност, захтева далеко утемељенију аргументацију и разраду, коју Онуф, међутим, не нуди. Такође, стиче се утисак да Онуфова теорија говорних аката избегава и критике упућене теоријама секуритизације, првенствено у вези са преуско постављеним одређењима секуритизујућег агента као политичке елите. Предност Онуфовог схватања је шира могућност примене на истраживање безбедносних појава и процеса, неограничених на традиционалне концепте безбедности фокусиране на државе као агенте, односно, оно чини могућим узимање у разматрање и свих оних безбедносно релевантних субјеката који се појављују и јачају у савременом добу.

Упркос наведеном, могућности примене Онуфове поставке ограничене су, како је већ указано, непрецизним и непотпуним одређењем кључних појмова (говорника, аудиторијума, али и самог говорног акта/ 
правила), као нужним условом за операционализацију било каквог метода. Неопходно је, нарочито када је реч о импликацијама на разматрање међународних односа и безбедности, одредити јасне услове који некога могу чинити говорником и креатором правила, одредити прецизно слушаоце, првенствено као оне који прихватају обавезивање или обећање, те одредити, конкретизованије него што то Онуф чини, који говорни акт се може сматрати легитимним, нарочито у контексту међународних норми које се тичу најзначајнијих безбедносних питања. Деликатна и озбиљна проблематика о којој је реч захтева да се у сваком тренутку и у сваком конкретном случају могу недвосмислено идентификовати сви елементи процеса којим говорни акт постаје правило.

Тек на претходно наведени начин идентификовани елементи стварају могућности за примену Онуфове теорије говорних аката као аналитичког метода за истраживање безбедносних феномена. Ова теорија поседује нарочити потенцијал као оквир за анализирање речи које највећим делом чине садржину државних и међународних политика, односно којима се у највећој мери формулишу и презентују утврђене политике. Све изјаве које су на известан начин од политичког значаја могу бити анализиране у контексту асертивних, директивних и комисивних говорних аката. Њиховом идентификацијом, која их диже до нивоа инструктивних, директивних или комисивних правила, ствара се могућност да се ти акти потом сортирају, како би се одредио однос између говорника и аудиторијума, разлике између тврдњи какво је нешто и евентуалних аспирација за будућност и томе слично. Таква анализа мало се разликује од директне интерпретације која се не заснива на теорији говорних аката, али категоризација различитих исказа омогућава структурисанији приступ интерпретацији. Оваквом идејом водио се и Рене Марлин-Бенет (Renée MarlinBennett) у свом есеју What is The American National Interest? Reading Obama with Onuf. Важно је поменути и ауторову сугестију да се уведе и додатни корак у анализи, што би представљало увођење неизречених правила како би изговорени искази имали смисла.

Говорећи о евентуалним недостацима Онуфовог поимања ове проблематике, очита је недоследност у излагању о правилима уопште. Недостатак логичног следа, односно редоследа у извођењу правила из говорних аката, а потом из њих и стања правила на једном месту, неизбежно доводи до конфузије. Осим поменуте недоследности, присутна је и терминолошка нејасноћа, и то коришћењем термина “правила" у више различитих значења (укључујући и разликовање правила (једнина) и правила (множина)). Изузетно значајно је указати и на присутно подразумевање поштовања одређених правила. Изнимно мали простор 
је посвећен, и то прилично површном објашњењу ситуација у којима долази до кршења правила. Занемаривање ситуација у којима је већа корист од кршења, или било којих других у којима до кршења правила долази, сугерише извођење потенцијално једностраних закључака. Наведено је нарочито упечатљиво у међународним односима, чијим примерима обилује историја (ратови из интереса). У том контексту, сматра се недовољним позивање на међународно право као ограничење.

Такође, и подразумевањем способности говора као јединог основа од значаја за друштвене односе, игнорише се у потпуности део популације у својству агентуре, или бар као фактора од утицаја на поменуте односе (а који апсолутно могу бити агенти без обзира на евентуалну немогућност говора). Недостатак је свакако и потпуно занемаривање неизговореног, прећутног и субјективног у друштвеним (и међународним) односима. Управо субјективна, психолошка компонента има великог утицаја на исходе понашања (“једно мисли, друго каже”, као и “једно мисли, друго ради”). Најзад, инструктивна правила далеко су општија и од директивних и од комисивних правила. Могло би се, условно, рећи да оба произилазе из њега, те се поставља питање колико је онда прикладно (оправдано) издвајати инструктивна као равноправна са директивним и комисивним правилима. Другим речима, уопштено посматрано, сва правила у крајњем дају извесне инструкције. И на овом месту се напомиње недостатак проистекао из занемаривања других фактора који утичу на исказ/изговорено (социјално-психолошких и психолошких уопште), а који последично доводи до тога да Онуфова три типа правила не исцрпљују све могућности перформативног говорног језика.

\section{Закључна разматрања}

Коначно, закључује се да међу најзначајнијим доприносима Онуфове теорије засноване на перформативном говору (заједно са правилима која производи) јесу свакако они видљиви на плану њене практичне примене. Имајући практичне импликације на разним нивоима друштвених (и међународних) односа, ова теорија чини се потенцијално плодоносном за примену као аналитички оквир за истраживање најразличитијих проблематика у области безбедности, а будући да је изговорено објективно мерљиво, подложно анализи и извлачењу разноврсних закључака, чак и статистичких показатеља. Уз предложене измене и дубљу разраду полазних основа у вези са одређењем говорника, слушалаца, а нарочито самих говорних аката и правила, оваква анализа могла би се применити 
на најзначајније политичке изјаве/документе, од говора политичких лидера, преко владиних докумената, па до оснивачких докумената и других текстова различитих регионалних и глобалних безбедносних организација. Новину у теоријском промишљању о правилима/нормама у домену међународних односа неизоставно представља и уочавање конститутивне и регулативне функције правила, чиме се, такође, проширује спектар могућности практичне примене. Напослетку, упутно је напоменути да извођење закључака о Онуфовом поимању легитимности међународног поретка, те класификација једноставних и комплексних институција извршена по основу критеријума доминације инструктивног, директивног или комисивног правила, захтева далеко већи простор за аргументацију и разраду него што то овај рад нуди, те стога заузима споредно место у раду. Но, потребно је указати, барем на основу понуђеног најопштијег објашњења, на потенцијал који може имати за дубље разумевање међународног система, као и експланаторну моћ коју поседује када је реч о самим међународним режимима. Илустративан је и приказ импликација овако одређених правила на агентуру, у смислу да један агент увек представља оличење комбинације статуса, положаја и улога, а које никада не може бити истоветно са оном неког другог агента, но поново, како ни Онуфово поимање агентуре није у фокусу овога рада, примерено је задржати се на овако уопштеној оцени. 


\section{ЛИТЕРАТУРА}

Balzaq, T. (2005). The Three Faces of Securitization: Political Agency, Audience and Context. European Journal of International Relations, (11) 2, 171-201.

Buzan, B., Wæver, O., de Wilde, J. (1998). Security - A New Framework Analysis. Colorado: Lynne Rinner Publishers, Inc., Boulder.

Ејдус, Ф. (2016). „Дискурзивна и практична конструкција међународне

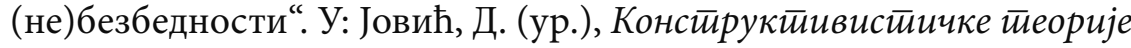
међунароgних оgноса. Загреб: Факултет политичких знаности, 199-228.

Guzzini, S. \& Leander, A. (2017). „Following Onuf's rules on rules: the legal road to social Constructivism“. In: Gould, H. (ed.), The Art of WorldMaking: Nicholas Greenwood Onuf and His Critics. London: Routledge, 175-188.

Katzenstein, J. P. (1996). „Introduction: Alternative Perspectives on National Security“. In: Katzenstein, J. P. (ed.), The Culture of National Security: Norms and Identities in World Politics. New York: Columbia University Press, 1-27. Преузето 24.6.2019. ca http://www.ciaonet.org/book/ katzenstein/katz01.html

Ковачевић, Б. (2016). „Што је то ново у конструктивизму?“. У: Јовић,

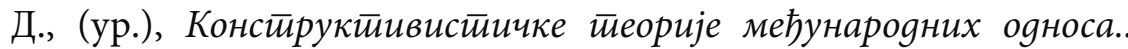
Загреб: Факултет политичких знаности, 37-88.

Kowert, P. (2017). „Making sense of our world: competence, reason, and the emergence of ethical systems“. In: Gould, H. D. (ed.), The Art of WorldMaking: Nicholas Greenwood Onuf and His Critics. London: Routledge, 127-142.

Marlin-Bennet, R. (2017). „What is the American national interest? Reading Obama with Onuf". In: Gould, H. D. (ed.), The Art of World-Making: Nicholas Greenwood Onuf and His Critics. London: Routledge, 146-156.

Onuf, N. (1994). The constitution of International Society. European Journal of International Law, 5(1), 1-19.

Onuf, N. (1989). World of Our Making: Rules and Rule in Social Theory and International Relations. Columbia: University of South Carolina Press.

Onuf, N. (2013). Making Sense, Making Worlds: Constructivism in social theory and international relations. London: Routledge.

Onuf, N. (2014). Rule and rules in international relations. Erik Castrén Institute of International Law and Human Rights, University of Helsinki [онлајн]. Преузето 2.фебруара 2018, ca http://www.helsinki.fi/eci/ Events/Nicholas\%20Onuf_Rule\%20and\%20Rules\%20\%204-2-14.pdf

Остин, Џ. (1980). Како gеловатии речима. Нови Сад: Матица српска. 
Puchala, D. J. \& Kegley, C. W. (1989). „Editor's Preface“. In: World of Our Making: Rules and Rule in Social Theory and International Relations. Columbia: University of South Carolina Press, ix-x.

Roberts, J. C. (2017). „What do rules do? Making room for rationality in Constructivist thought". In: Gould, H. D. (ed.), The Art of World-Making: Nicholas Greenwood Onuf and His Critics. London: Routledge, 80-90.

Серл, Џ. (1991). Говорни чинови: оїлеg из филозофије језика. Београд: Нолит.

Stritzel, H. (2007). Towards a Theory of Securitization: Copenhagen and Beyond. European Journal of International Relations, (13)3, 357-383.

Шуловић, В. (2010). Значење концепта безбедности и теорија секуритизације. Београдски центар за безбедносну политику. Преузето 4. 9. 2019. ca bezbednost.org/Bezbednost/714/Znacenjekoncepta-bezbednosti-i-teorija.shtml

Tickner, A. (2017). „Foreword“. In: Gould, H.D. (ed.), The Art of World-Making: Nicholas Greenwood Onuf and His Critics. London: Routledge, xiv.

Вент, А. (2014). Друшиивена йеорија међунарояне йолийике. Београд: Факултет политичких наука.

Wæver, O. (1995). „Securitization and Desecuritization“. In: Lipschutz, R. (ed.), On Security. New York: Columbia University Press, 46-86.

Wiener, A. (2017). „Still missing the other half: world making and sense making“. In: Gould, H. D. (ed.), The Art of World-Making: Nicholas Greenwood Onuf and His Critics. London: Routledge, 113-123. 


\title{
ONUF'S SPEECH ACT THEORY - IMPLICATIONS ON RESEARCH IN SECURITY STUDIES
}

\author{
Nevena Stanković, PhD Student \\ University of Belgrade, Faculty of Security Studies
}

\begin{abstract}
Summary
The focus of this research is a speech act theory of one of the most influential social constructivists - Nicholas Onuf. After a review of the most important premises about the rules, as a central concept to his approach (consequently, including the conditions of rule), the author attempts to represent the role and the significance that performative language has in international relations field, as much as in social relations in general. A central part of this paper is about speech act theory as an inclusive set of categories of the rules (instructive, directive and commissive), implications of the rules on the agency, and observed connection with legality of the international system. Eventually, the author made conclusions on contribution and possibilities of implementation in practice of the Onuf's speech act theory, primarily as an analytical tool for the research in security studies, and also eminent flaws, with the suggestions in order to overcome them. In conclusion, it appears that the potential contribution of Onuf's approach to this theme in security studies, and also to international relations, is extremely significant, but there is a need for further elaboration and emendation so that his theoretical position could have larger explanatory power for implementation.
\end{abstract}

Keywords: Onuf, speech act theory, rules, analytical tool, research in security studies. 